J. Amer. Soc. Hort. Sci. 115(2):218-225. 1990.

\title{
Variation in and Relationship of Biomass, Growth Rate, Harvest Index, and Phenology to Yield of Common Bean
}

\author{
B.T. Scully' and D.H. Wallace ${ }^{2}$ \\ Department of Plant Breeding and Biometry, Cornell University, Ithaca, NY 14853 \\ Additional index words. biomass growth rate, days to flower, days to maturity, days of pod fill, Phaseolus vulgaris, \\ seed growth rate, sink strength
}

\begin{abstract}
A diverse set of 112 common bean (Paseolus vulgaris L.) accessions were evaluated for variation in eight traits related to yield over a 2-year period. Days to flower, days of pod fill, and days to maturity ranged from 25 to 66, 44 to 83, and 70 to 133, respectively, in upstate New York: Yield and biomass ranged from 81 to 387 and 270 to

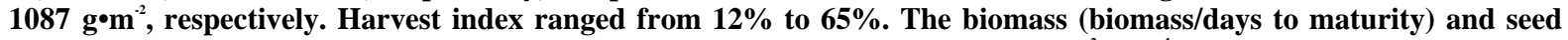

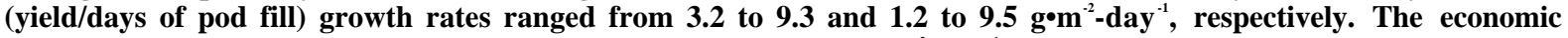

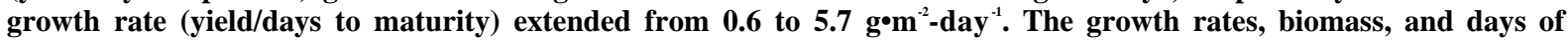
pod fill were linearly and positively related to yield. Biomass and the growth rates explained a large amount of the variation in yield, with $r^{2}$ values between 0.71 and 0.84 ; days of pod fill explained the least, with $r^{2}=0.09$. Yield followed a curvilinear relationship with days to flower and days to maturity; yield was maximized at 48.5 days to flower and 112.2 days to maturity. Yield was a quadratic function of harvest index and maximized at 57.2\%. Among these three curvilinear traits, days to flower explained $80 \%$ of the variation in yield, while days to maturity and harvest index accounted for $25 \%$ and $12.5 \%$, respectively. The "ideal" genotype for New York was defined at these maximum values for harvest index, days to maturity, days to flower, and at 63.7 days of pod fill. Additionally, a simple equation is proposed to aid breeders in the selection of common bean accessions with strong sink strength. It is defined as "relative sink strength": $\mathrm{RSS}=$ seed growth rate/biomass growth rate. Values $>1.0$ implied strong sink capacity in common beans.
\end{abstract}

Direct selection for increased yield among grain legume species has fallen short of expectations (Evans, 1980). Improvement of yield by indirect selection with physiological or biochemical measures of photosynthetic traits has also disappointed many breeders (Apel, 1984; Beadle et al. 1985; Evans, 1984; Sherrard et al., 1984). This situation does not imply that photosynthesis and crop yield are unrelated; rather, it indicates that some measures of photosynthesis are inappropriate estimators of yield potential (Good, 1986). Zelitch (1982) has argued that "instantaneous measures" of photosynthesis are not indicative of crop yield or net $\mathrm{CO}_{2}$ assimilation on a seasonal basis. This "paradox" (Zelitch, 1982) is further complicated by the theoretical criteria of indirect selection (Searle, 1965; Turner and Young, 1969). To be effective, an indirect trait must have a higher heritability than, and also have a high genetic correlation with, the final trait of interest. In common beans,

Received for publication 9 Nov. 1988. Part of a dissertation submitted by B.T.S. in partial fullfilment of the requirements for the $\mathrm{PhD}$ degree. Research supported by USAID Title XII Bean/Cowpea CRSP, USDA Hatch Act funds, and the New York State Agriculture Experiment Station. Plant Breeding and Biometry Paper no. 779. The cost of publishing this paper was defrayed in part by the payment of page charges. Under postal regulations, this paper therefore must be hereby marked advertisement solely to indicate this fact.

'Forrner Graduate Research Assistant. Presently Assistant Professor, Texas Agriculture Experiment Station, Texas A\&M Univ., Weslaco, TX 78596-8399. ${ }^{2}$ Professor of Plant Breeding and Biometry.
Wallace et al. (1975) and Wallace (1980) showed that these theoretical criteria were not met, although genetic variation did exist for photosynthetic rates. They addressed this problem with a type of growth analysis that integrated the processes of photosynthesis and partitioning. It provided insight into crop yield, but produced little fundamental information about photosynthesis itself (Beadle et al., 1985).

Crop yield can be characterized as a function of an organism's: 1) adaptation to its environment; 2) ability to effectively harvest light with the photosynthetic apparatus; and 3) ability to partition and translocate photosynthate to the economic organs (Apel, 1984; Evans, 1983, 1984; Gifford and Evans, 1981; Gifford et al., 1984; Good and Bell, 1980). These processes are measured in various ways by breeding programs. Phenological adaptation is best measured by days to maturity and the concomitant days to flower and of pod fill (Evans, 1984). Biomass and the biomass growth rate are indicative of the lightharvesting ability of the crop canopy. Harvest index measures assimilate distribution, and seed growth rate measures the rate of assimilate translocation and sink strength. Additionally, an economic growth rate can be developed to relate the length of crop's life cycle to yield.

Biomass, yield, growth rates, harvest index, and phonological traits all all within the purview of the ideotype concept. Rasmussen (1987) has expanded the ideotype definition, which is based on morphological traits, to include both phonological and 
physiological traits. He grouped them in the categories of "growth period", and "growth rate". Wallace and Masaya (1988) have suggested that these traits collectively provide an integrated measure of crop productivity, and opted to group them together as "yield system" traits. Adams (1982), and Sinha and Swaminathan (1984) have suggested that some or all of these traits are useful for crop improvement.

The purpose of this investigation was to: 1) explore for biological diversity in these yield system traits across a broad genetic base of common beans; and 2) evaluate the relationship of yield to each.

\section{Materials and Methods}

Common bean accessions of diverse origin and adaptation were grown in upstate New York during the summers of 1986 and 1987. The 112 accessions included 18 black, 16 brown/tan, 6 dark red kidney, 15 light red kidney, 12 pinto/cranberry, 3 red mexican, 13 small white, 4 snap bean, and 25 miscellaneous types. These entries were randomly drawn from a germplasm collection of more than 350 accessions. Of the 112 accessions, 93 were collected in either North (55), Meso (18), or South (20) America, with the balance coming from Africa and Europe. In 1986, experiments were planted at the East Ithaca, Freeville, and Mt. Pleasant Research farms. Respectively, the soils found at these sites included: 1) Arkport fine sandy loam (coarseloamy, mixed, mesic Psammentic Hapludalfs); 2) Howard gravely loam (loamy skeletal, mixed mesic Glassoboric Hapludalfs); and 3) Mordin Channery silt loam (fine loamy, mixed, mesic Typic Fragiochrepts). In 1987, adjacent fields were planted on the same soils; however, the planting on Mt. Pleasant failed. In both years, the fields were prepared with $450 \mathrm{~kg}$-hal of $10 \mathrm{~N}-20 \mathrm{P}-20 \mathrm{~K}$ fertilizer and 1.3 and $1.6 \mathrm{liter} \cdot \mathrm{ha}^{-1}$ of Dual and Treflan, respectively. Seeding was at a depth of $40 \mathrm{~mm}$ in the first week of June. Plots were not irrigated. A single mechanical cultivation was performed in the first week of July; further weeding was done manually. A single application of maneb was used at commercial rates in the 1986 Freeville planting to control anthracnose [Colletotrichum lindemulhianum (Sacc. \& Magm)Scrib.], gray mold (Botrytis cinerea Pers. ex Fries.), and white mold [Sclerotinia (Whetzelinia) sclerotiorum (Lib.) de Bary].

The experiment was a completely randomized design (Federer, 1955) with three replications in each of five site-year environments. The plots were single $1.7-\mathrm{m}$ rows planted with 25 seeds, and spaced at $\pm 1.0 \mathrm{~m}$ to avoid intergenotypic competition. Plots were arranged so that nearest neighbors were the same only by chance to remove any systematic error due to adjacent plots. The perimeter of each field included buffer rows. At maturity, plants from the central meter from each whole plot were harvested; air-dried to $\approx 12 \%$ moisture, and threshed, with results expressed on a square-meter basis.

All traits were measured on a whole-plot basis. These included: 1) days to flower (DTF), determined as the days from $50 \%$ seedling emergence to $50 \%$ anthesis (defined when $50 \%$ of the plants in a plot had at least one open flower); 2) days of pod fill (DPF), determined from $50 \%$ anthesis to $90 \%$ physiological pod maturity (defined when pods had yellowed); 3 ) days to maturity (DTM), from $50 \%$ emergence to $90 \%$ pod maturity; 4) biomass was measured as the defoliated aerial portion of the plant; and 5) seed yield. Phonological data were taken at each site every third day.

Traits calculated from these data included: 1) harvest index $(\mathrm{HI}) ; 2$ ) seed growth rate (SGR); 3) biomass growth rate (BGR); and 4) an economic growth rate (EGR), all determined as (seed yield/biomass) $\times 100$; seed yield/days of pod fill; biomass/days to maturity; and seed yield/days to maturity, respectively. Data were analyzed by unweighed regression analysis using PROC GLM, REG, RSQUARE, and UNIVARIATE (SAS, 1985). Mean yield for each accession was evaluated as a function of the mean of the other traits.

\section{Results and Discussion}

Biological diversity. Biological variation existed for all the traits screened in this study (Table 1). Coefficients of skewness, kurtosis, and Kolomogorov's D were used to further describe the frequency distribution of each trait (Larsen and Marx, 1985; Mood et al., 1974; SAS, 1985). Positive skewness indicated that the peak was skewed to the left of the mean, with a longer right tail. Negative skewness was the opposite. Positive kurtosis indicated a greater density of observations around the peak than in a normal distribution and suggested reduced variability and greater biological conservation of a trait. Traits with a negative kurtosis were flatter around the peak and showed greater biological variation. All traits, except harvest index (HI) and the economic growth rate (EGR), fit the normal distribution at a criterion of $P_{\alpha} \geq 0.05$, although days to flower (DTF) approached significance with $P_{\alpha}=0.051$ (Table 1).

The skewness of HI and DTF was explained by the many neotropical entries in this experiment. Most of these accessions flowered late (after 21 July) in upstate New York due to photoperiod sensitivity (Wallace, 1985). This lengthened the right tail of the distribution and resulted in a positive skewness for DTF. Conversely, these accessions had more vegetative biomass at anthesis, a shortened and late seed fill duration, and thus lower HI. This produced the negative skewness in HI. The negative skewness of the EGR maybe a function of the diseases and pests that were present on these exotic accessions, although seed growth rate (SGR) and biomass growth rate (BGR) were not skewed seriously.

Positive kurtosis suggests stabilizing selection that maintains adaptation; however, it can also be an artifact of the data set. Traits that are constrained by a narrow theoretical range have a propensity for positive kurtosis, particularly as the number of observations within the range increases. The theoretical domain of all the yield system traits is ultimately defined by climate. Short growing seasons suggest a narrow range of adaptation and the tendency for positive kurtosis, given an adequately large sample size.

In this study, seven of the nine traits were positively kurtotic (Table 1). Harvest index had the narrowest range and, as a result, the highest kurtosis (Table 1). Genotypes with lower HI reproduced marginally, but as $\mathrm{HI}$ increased, fecundity improved sharply. At HI > 60\%, biomass and subsequent yield dropped off steeply, even though the mode in this experiment was $58 \%$ to $59 \%$ (23 accessions). An upper limit was reached around $65 \%$. Generally, these accessions flowered and matured the earliest but exceptions did exist (Table 4).

Phonological adaptation. The range in days to maturity (DTM) was $\approx 63$. DTM explained $25 \%$ of the variation in yield, which was a quadratic function of DTM (Fig. 1 left, Table 2). Yield (YLD) was maximized at 112.2 days and determined by the first derivative maximum $\left(d_{\text {YLD }} / d_{\text {ртм }}=0.0\right)$. This critical point was confirmed with a second derivative test (Arya and Lardner, 1979). The inflection points were used to define an optimum biological range of maturity, such that: $d_{Y L D} / d_{\text {DTM }}=25.49-$ $0.227(\mathrm{DTM})= \pm 1.0$. At a slope of 1.0 , DTM $=107.8$; at 
Table 1. Biological variation in yield system traits for 112 accessions.

\begin{tabular}{|c|c|c|c|c|c|c|c|}
\hline \multirow[b]{2}{*}{ Trait } & \multirow[b]{2}{*}{ Mean } & \multicolumn{2}{|c|}{ Range } & \multirow[b]{2}{*}{ SD } & \multirow[b]{2}{*}{ Skewness } & \multirow[b]{2}{*}{ Kurtosis } & \multirow{2}{*}{$\begin{array}{c}\text { Kolomogorov's } \\
\text { D } \\
\end{array}$} \\
\hline & & Min. & Max. & & & & \\
\hline Days to flower (DTF) & 36.8 & 25.1 & 65.5 & 6.8 & 0.96 & 1.94 & 0.084 \\
\hline Days of pod fill (DPF) & 62.9 & 44.2 & 83.0 & 8.9 & 0.27 & -0.33 & 0.077 \\
\hline Days to maturity (DTM) & 99.5 & 70.0 & 133.0 & 13.5 & 0.27 & -0.26 & 0.054 \\
\hline Yield $\left(\mathrm{g} \cdot \mathrm{m}^{-2}\right)$ & 344.0 & 81.2 & 587.0 & 85.9 & -0.06 & 0.36 & 0.056 \\
\hline Biomass $\left(\mathrm{g} \cdot \mathrm{m}^{-2}\right)$ & 630.0 & 270.0 & 1087.0 & 158.0 & 0.45 & 0.24 & 0.078 \\
\hline Harvest index (\%) & 55.1 & 12.0 & 64.8 & 7.10 & -2.67 & 12.34 & $0.124^{* *}$ \\
\hline Seed growth rate $(\mathrm{SGR})^{z}$ & 5.6 & 1.2 & 9.5 & 1.35 & -0.07 & 1.00 & 0.072 \\
\hline Biomass growth rate (BGR)y & 6.3 & 3.2 & 9.3 & 1.09 & -0.02 & 0.22 & 0.036 \\
\hline Economic growth rate $(\mathrm{EGR})^{\mathrm{x}}$ & 3.5 & 0.6 & 5.7 & 0.75 & -0.57 & 1.92 & $0.111^{* *}$ \\
\hline
\end{tabular}

${ }^{z}$ Seed growth rate $=$ yield/days of pod fill $\left(\mathrm{g} \cdot \mathrm{m}^{-2} \cdot \mathrm{day}^{-1}\right)$.

yBiomass growth rate $=$ biomass/days to maturity $\left(\mathrm{g} \cdot \mathrm{m}^{-2} \cdot \mathrm{day}^{-1}\right)$.

${ }^{x}$ Economic growth rate $=$ yield/days to maturity $\left(\mathrm{g} \cdot \mathrm{m}^{-2} \cdot \mathrm{day}^{-1}\right)$.

** Significant at $P_{\alpha} \leq 0.01$.

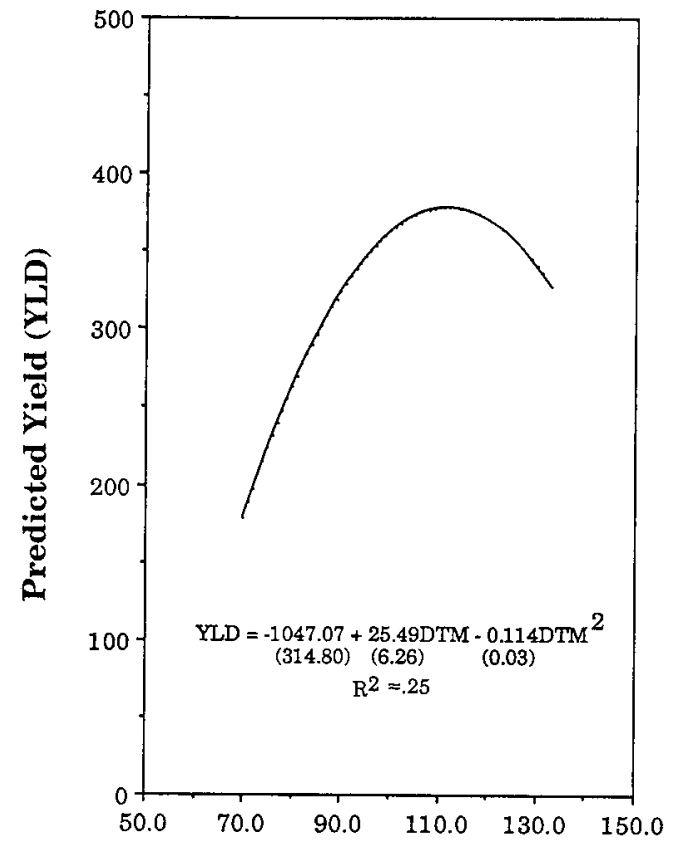

Days to Maturity (DTM)

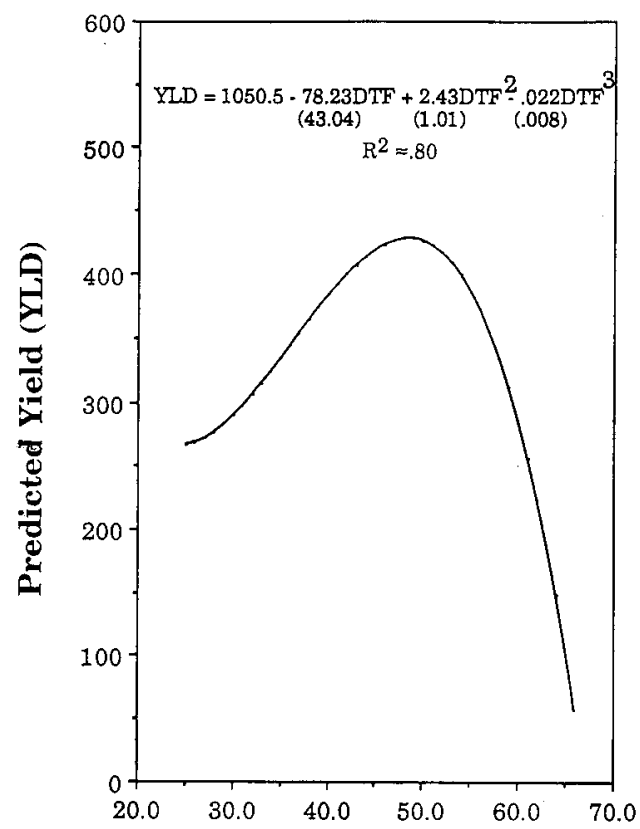

Days to flower (DTF)

Fig. 1. (left) Predicted yield $\left(\mathrm{g} \cdot \mathrm{m}^{-2}\right)$ of common beans as a function of days to maturity, with sES of the regression coefficients shown parenthetically. (right) Predicted yield $\left(\mathrm{g} \cdot \mathrm{m}^{-2}\right)$ of common beans as a function of days to flower, with sES of the regression coefficients shown parenthetically.

a slope of -1.0, DTM $=116.6$. Of the 112 accessions, 19 matured within this range; six were neotropical, and 13 temperate. Twelve accessions matured later than 116.6 days; 11 were neotropical and the 12th was 'Linden', a light red kidney bean from California (Table 4).

Days to maturity was subdivided into days to flower (DTF) and days of pod fill (DPF) to assess the effect of phenology on yield. YLD was defined as a cubic function of DTF (Fig. 1 right, Table 2). The critical points were determined at: $\mathrm{DTF}_{\text {min }}$ $=24.0$, and $\mathrm{DTF}_{\max }=48.5$ days. Because $\mathrm{DTF}_{\min }$ fell below the observed range of this trait, it was not considered biologically important. An optimum range around $\mathrm{DTF}_{\max }$ was defined at the inflection points as: $d_{\mathrm{YLD}} / d_{\mathrm{DTF}}=-78.23+4.866(\mathrm{DTF})-0.0671$ $(\mathrm{DTF})^{2}= \pm 1.0$, and determined to be 47.9 and 49.0 DTF- No accession flowered within this narrow range of 1.1 days; however, six tropical accessions flowered later than 49.0 days. 'Emp83' was close-it flowered in 52 days and had exceptional yield; 'Limelight' had the shortest days to flower (Table 4).

Days to flower explained nearly $80 \%$ of the variation in yield, compared to $25 \%$ for DTM (Fig. 1 right; Table 2). Therefore, DTF was considered the more important trait for the description of adaptation and yield. The significance of the cubic function resulted from accessions that flowered in August. These accessions had pod fill durations shortened by cold weather and therefore produced only nominal yields (Fig. 1 right). Conversely, accessions that flowered between 25 and 30 days had low but stable yields, which further contributed to the significance of the cubic function (Fig. 1 right). 
Table 2. Regression analysis of variance for seed yield as a function of each yield system trait for 112 common bean accessions.

\begin{tabular}{|c|c|c|c|}
\hline $\begin{array}{l}\text { Source of } \\
\text { variation }^{z}\end{array}$ & $\mathrm{df}$ & $\begin{array}{c}\text { Type I } \\
\text { mean squares }\end{array}$ & $\begin{array}{c}\mathrm{F} \\
\text { value }\end{array}$ \\
\hline \multicolumn{4}{|c|}{ Days to flower (DTF) } \\
\hline Total & 111 & 7,387 & \\
\hline DTF linear & 1 & 118,246 & 25.99 \\
\hline DTF quadratic & 1 & 176,082 & 38.70 \\
\hline DTF cubic & 1 & 38,224 & 8.40 \\
\hline Lack-of-fit & 1 & 559 & 0.12 NS \\
\hline Error & 107 & 4,550 & \\
\hline \multicolumn{4}{|c|}{ Days of pod fill (DPF) } \\
\hline Total & 111 & 7,387 & \\
\hline DPF linear & 1 & 74,240 & 11.18 \\
\hline Lack-of-fit & 1 & 21,648 & $3.26 \mathrm{NS}$ \\
\hline Error & 109 & 6,643 & \\
\hline \multicolumn{4}{|c|}{ Days to maturity (DTM) } \\
\hline Total & 111 & 7,387 & \\
\hline DTM linear & 1 & 123,295 & 22.12 \\
\hline DTM quadratic & 1 & 77,458 & 13.90 \\
\hline Lack-of-fit & 1 & 17,168 & $3.08 \mathrm{NS}$ \\
\hline Error & 108 & 5,574 & \\
\hline \multicolumn{4}{|c|}{ Biomass } \\
\hline Total & 111 & 7,387 & \\
\hline Biomass linear & 1 & 606,636 & 316.84 \\
\hline Lack-of-fit & 1 & 4,608 & $2.41 \mathrm{NS}$ \\
\hline Error & 109 & 1,914 & \\
\hline \multicolumn{4}{|c|}{ Harvest index $(H I)$} \\
\hline Total & 111 & 7,387 & \\
\hline HI linear & 1 & 62,199 & 9.39 \\
\hline HI quadratic & 1 & 40,614 & 6.14 \\
\hline Lack-of-fit & 1 & 1,558 & $0.24 \mathrm{NS}$ \\
\hline Error & 108 & 6,625 & \\
\hline \multicolumn{4}{|c|}{ Seed growth rate (SGR) } \\
\hline Total & 111 & 7,387 & \\
\hline SGR linear & 1 & 583,257 & 269.80 \\
\hline Lack-of-fit & 1 & 1,036 & 0.48 NS \\
\hline Error & 109 & 2,162 & \\
\hline \multicolumn{4}{|c|}{ Biomass growth rate (BGR) } \\
\hline Total & 111 & 7,387 & \\
\hline BGR linear & 1 & 691,971 & 590.37 \\
\hline Lack-of-fit & 1 & 209 & 0.18 NS \\
\hline Error & 109 & 1,172 & \\
\hline \multicolumn{4}{|c|}{ Economic growth rate (EGR) } \\
\hline Total & 111 & 7,387 & \\
\hline EGR linear & 1 & 601,124 & 301.11 \\
\hline Lack-of-fit & 1 & 1,210 & $0.61 \mathrm{NS}$ \\
\hline Error & 109 & 1,996 & \\
\hline
\end{tabular}

${ }^{z}$ Total $=$ corrected for the mean.

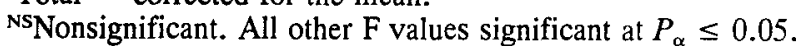

The relationship between YLD and DPF was linear, positive (Table 2), and defined as:

$$
\begin{gathered}
\text { YLD }=161.32+2.91(\mathrm{DPF}) \\
\mathrm{SE}( \pm 55.76)( \pm 0.88)
\end{gathered}
$$

Only $9 \%\left(r^{2}=0.09\right)$ of the variation in yield was explained by the pod fill duration. Of these three phonological traits, DPF provided the least insight into the adaptation and yield of common beans.

The joint effect of DTF and DPF was best described by a five-variable multiple regression model that included only the linear $\mathrm{x}$ linear interaction (Fig. 2, Table 3). This model was selected because it had the same order of main effects as the simple models (Table 2), and a Mallows $\mathrm{Cp}=5.12$ (Draper and Smith, 1981). Because pod fill duration was linear, no local maximum existed (Fig. 2). A series of maximums and minimums existed for DTF when DPF was fixed over its range of 44 to 84 days (Table 1 ). These points were defined by the partial derivative of yield with respect to DTF, as:

$\partial_{\mathrm{YLD}} / \partial_{\mathrm{DTF}}=-165.96+10.15(\mathrm{DTF})-0.122(\mathrm{DTF})^{2}-$ $0.50(\mathrm{DPF})=0.0$.

Thus:

$\mathrm{DTF}_{\max . \mathrm{DPF}}=\left\{24766.2(88.6-\mathrm{DPF})^{1 / 2}+507328.0\right\} / 12234.0$ defined the "ridge line" and the zone of maximum yield; while $\mathrm{DTF}_{\text {min. DPF }}=-\left\{24766.2(88.6-\mathrm{DPF})^{1 / 2}+507328.0\right\} / 12234.0$ defined the "valley bottom" (Fig. 2). The valley bottom had limited biological meaning at the lower end, but a significant number of red kidney types were clustered at the upper end of D $T \mathrm{~F}_{\text {min.DPF. }}$ This model explained only $45 \%$ of the variation in yield. The cubic days to flower model (Fig. 1 right) was still more important with an $R^{2} \approx 0.80$, and therefore used to define an optimum.

The adaptation of common beans in New York was most influenced by flowering time. The determination of a unique combination of days to flower and days of pod fill for maximum yield was determined indirectly and governed by the optimum flowering time, such that:

$$
\mathrm{DTM}_{\text {max }}-\mathrm{DTF}_{\max }=\mathrm{DPF}_{\text {opt. }}
$$

Previously, $\mathrm{DTM}_{\max }$ was defined at 112.2 days, and $\mathrm{DTF}_{\max }$ at 48.5 days (Fig. 1 left and right). By subtraction, DPF $=63.7$ days. On average, most accessions flowered in 36.8 days and filled pods over 63 days (Table 1). These data suggest that increased yield would best result from selection that emphasized the duration of the vegetative phase, rather than the reproductive phase.

Partitioning and biomass. The relationship between yield and HI was curvilinear over the observed range of 12 to $65 \%$ (Fig. 3; Tables 1 and 2). Yield was maximized at: $\mathrm{HI}_{\max }=57.2 \%$. The optimum range was defined at:

$$
\partial_{\mathrm{YLD}} / \partial_{\mathrm{HI}}=16.72-0.292(\mathrm{HI})= \pm 1.0
$$

and occurred between $53.8 \%$ and $60.6 \%$. More than half the accessions fell within this range, and 18 had $\mathrm{HI} \geq 61.0 \%$. The tropical accession 'V-7593', followed by 'Ms. Kelly', had the highest HI (Table 4). This optimum range was similar to that reported by Wallace and Munger (1966), but higher than the results commonly reported across North America, or Latin America, where indeterminate vine types are often grown (Myers, 1987; Laing et al., 1983). Harvest index explained only $12.5 \%$ of the variation in yield (Fig. 3); multiple partial correlation analysis suggested that most of this variation was related through biomass (Table 5) (Neter et al., 1985).

Unlike the curvilinear relationship with HI, yield was, as expected, linear, positive, and highly correlated with total plant biomass (Fig. 4, Table 2). This relationship, after adjustment for differences in maturity time (Table 5), suggested biomass as a critical trait for the improvement of yield in common beans. The low slope (Fig. 4) indicated that improvements in biomass would not produce immediate or dramatic gains in yield, but the close relationship $\left(r^{2} \approx 0.74\right)$ warrants more consideration 


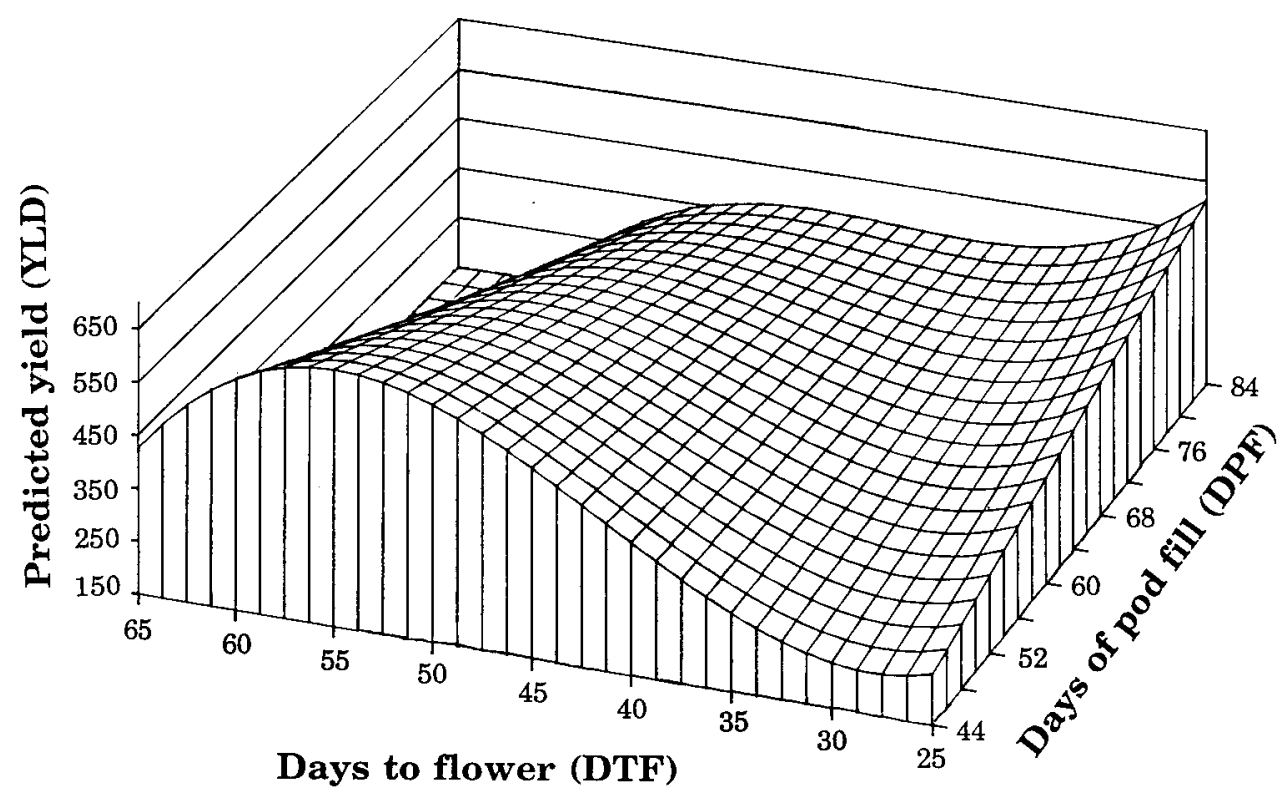

Fig. 2. Predicted yield $\left(\mathrm{g} \cdot \mathrm{m}^{-2}\right)$ of common beans as a function of both days to flower and days of pod fill. The response surface was defined by the equation $\left(R^{2}=0.45\right)$, with SES of the regression coefficients shown parenthetically:

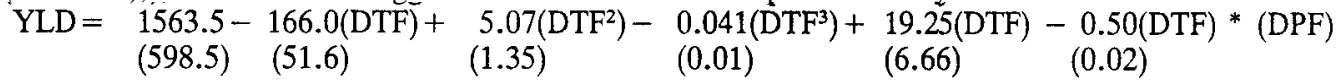

Table 3. Multiple regression analysis of variance for seed yield as a function of days to flower (DTF) and days of pod fill (DPF) for 112 common bean accessions.

\begin{tabular}{lccr}
\hline \hline Source of variation & df & $\begin{array}{c}\text { Type } \mathrm{I}^{\mathbf{z}} \\
\text { mean squares }\end{array}$ & $\begin{array}{c}\mathrm{F}^{\mathrm{y}} \\
\text { value }\end{array}$ \\
\hline Total CFM & 111 & 7,387 & \\
Model & 5 & 73,757 & \\
DPF linear & {$[1]$} & 74,240 & 17.44 \\
DTF linear & {$[1]$} & 58,649 & 13.78 \\
DTF quadratic & {$[1]$} & 162,814 & 38.25 \\
DTF cubic & {$[1]$} & 39,244 & 9.22 \\
DTF $\times$ DPF & & & \\
$\quad$ (Linear $\times$ linear) & {$[1]$} & 33,840 & 7.95 \\
Error & 106 & 4,256 & \\
\hline
\end{tabular}

zType III mean squares were also significant at a minimum of $P_{\alpha} \leq$ 0.05 .

yAll $\mathrm{F}$ values were significant at $P_{\alpha} \leq 0.01$.

in the selection for yield. These data contrast with results found in wheat (Triticum aestivum L. em. Thell.) (Austin et al., 1980) and peanuts (Arachis hypogea L.) (Duncan et al., 1978), where higher yields were related to increased harvest indices rather than increased biomass.

Growth rates. The average growth rates of common beans (Table 1) were generally lower than those found in other crops. These differences are primarily a function of species and environment, but may also be influenced by the measurement techniques unique to each crop. In barley (Horteum vulgare L.), Rasmussen (1987) reported average seed (SGR) and biomass (BGR) growth rates of 9.0 to 10.8 , and 9.1 to 10.2 $\mathrm{gm} \cdot \mathrm{m}^{-2} \cdot \mathrm{day}^{-1}$, respectively. Peanuts, soybeans [Glycine max (L.) Merr.], and durham wheat (Triticum turgidum L.) had average SGR of 4.0 to $9.5,6.7$ to 11.0 , and 5.5 to $8.5 \mathrm{~g} \cdot \mathrm{m}^{-2} \cdot$ day-1, respectively (Duncan et al., 1978; Boerma and Ashley, 1988; Gay et al., 1980; Knott and Gebeyehou, 1987). Duncan et al.

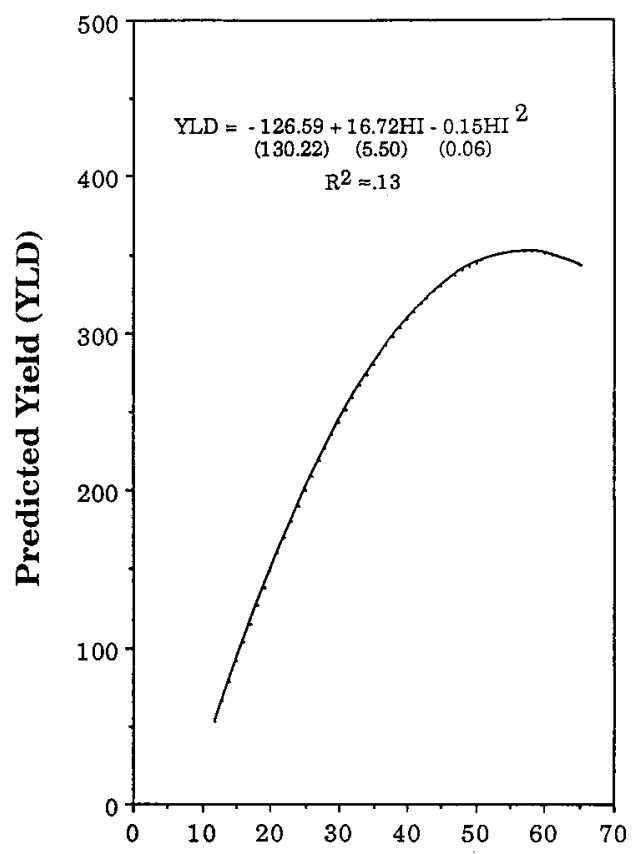

Harvest Index (HI)

Fig. 3. Predicted yield $\left(\mathrm{g} \cdot \mathrm{m}^{-2}\right)$ of common beans as a function of harvest index (\%), with SES of the regression coefficients shown parenthetically.

(1978) further reported biomass growth rates in peanuts at 18.5 to $21.5 \mathrm{~g} \cdot \mathrm{m}^{-2} \cdot \mathrm{day}^{-1}$. Accessions with high seed and biomass growth rates were found in this study (Table 4). For any given accession, we expected that the economic growth rate (EGR) was less than SGR, which, in turn, was less than BGR. Seed growth rate was expected to be lower than BGR because seed 
Table 4. Accessions with diverse values for yield system traits.

\begin{tabular}{llcccccccc}
\hline \hline $\begin{array}{l}\text { Cultivar } \\
\text { or line }\end{array}$ & $\begin{array}{c}\text { Seed } \\
\text { type }\end{array}$ & $\begin{array}{c}\text { Days to } \\
\text { maturity }\end{array}$ & $\begin{array}{c}\text { Days to } \\
\text { flower }\end{array}$ & $\begin{array}{c}\text { Days of } \\
\text { pod fill }\end{array}$ & $\begin{array}{c}\text { Yield } \\
\left(\mathrm{g} \cdot \mathrm{m}^{-2}\right)\end{array}$ & $\begin{array}{c}\text { Biomass } \\
\left(\mathrm{g} \cdot \mathrm{m}^{-2}\right)\end{array}$ & $\begin{array}{c}\text { Harvest } \\
\text { index }\end{array}$ & $\begin{array}{c}\text { Seed } \\
\text { growth } \\
\text { rate }^{z}\end{array}$ & $\begin{array}{c}\text { Biomass } \\
\text { growth } \\
\text { ratey }^{y}\end{array}$ \\
\hline A-343 & Cream & 98 & 43 & 55 & 488 & 782 & 0.62 & 8.99 & 8.05 \\
Emp-83 & Yellow & 126 & 52 & 74 & 520 & 1024 & 0.50 & 6.96 & 8.09 \\
Jamapa & Black & 100 & 40 & 60 & 479 & 792 & 0.61 & 8.28 & 8.00 \\
Limelight & White & 70 & 25 & 45 & 180 & 297 & 0.59 & 3.95 & 4.23 \\
Linden & Kidney & 122 & 39 & 83 & 470 & 1016 & 0.47 & 5.66 & 8.29 \\
Ms. Kelly & Pinto & 88 & 36 & 52 & 369 & 582 & 0.64 & 7.19 & 6.63 \\
Peru-34 & Kidney & 128 & 45 & 83 & 485 & 1087 & 0.44 & 5.85 & 8.46 \\
PI 310740 & Black & 104 & 42 & 62 & 588 & 962 & 0.61 & 9.50 & 9.27 \\
Suchitan & Black & 101 & 42 & 59 & 501 & 857 & 0.58 & 8.69 & 8.58 \\
Turrialba-2 & Black & 106 & 41 & 65 & 519 & 896 & 0.58 & 8.07 & 8.48 \\
V-7593 & Black & 95 & 36 & 59 & 376 & 585 & 0.65 & 6.39 & 6.14 \\
\hline
\end{tabular}

${ }^{{ }^{2}}$ Seed growth rate $=$ yield/days of pod fill $\left(\mathrm{g} \cdot \mathrm{m}^{-2} \cdot \mathrm{day}^{-1}\right)$.

yBiomass growth rate $=$ biomass/days to maturity $\left(\mathrm{g} \cdot \mathrm{m}^{-2} \cdot \mathrm{day}^{-1}\right)$.

Table 5. Squared first-order partial correlations and squared simple correlations for yield system traits based on ratios.

\begin{tabular}{|c|c|}
\hline $\begin{array}{l}\text { First-order partial/ } \\
\text { multiple partial } \\
\text { correlations }^{\mathbf{z}} \\
\end{array}$ & Simple correlations ${ }^{y}$ \\
\hline$r^{2}{ }_{\text {YLD,BMS-DTM }}^{x}=0.84$ & $\begin{array}{l}r_{\mathrm{YLD}, \mathrm{BMS}}^{2}=0.74 \\
r_{\mathrm{YLD}, \mathrm{DTM}}^{2}=0.15 \\
\mathrm{r}_{\mathrm{BMS}, \mathrm{DTM}}^{2}=0.54\end{array}$ \\
\hline$r^{2}{ }_{\mathrm{YLD}, \mathrm{SGR}, \mathrm{DPF}}=0.69$ & $\begin{array}{l}r_{\mathrm{YLD}, \mathrm{SGR}}^{2}=0.71 \\
r_{\mathrm{YLD}, \mathrm{DPF}}^{2}=0.09 \\
r_{\mathrm{SGR}, \mathrm{DPF}}^{2}=0.06\end{array}$ \\
\hline$r_{\mathrm{YLD}, \mathrm{BGR} \cdot \mathrm{DTM}}^{2}=0.84$ & $\begin{array}{l}r_{\text {YLD,BGR }}^{2}=0.84 \\
r_{\text {YLD,DTM }}^{2}=0.15 \\
r_{\text {BGR,DTM }}^{2}=0.08\end{array}$ \\
\hline$r_{\mathrm{YLD}, \mathrm{EGR} \cdot \mathrm{DTM}}^{2}=0.78$ & $\begin{aligned} r_{\mathrm{YLD}, \mathrm{EGR}}^{2} & =0.73 \\
r_{\mathrm{YLD,DTM}}^{2} & =0.15 \\
r_{\mathrm{EGR}, \mathrm{DTM}}^{2} & =0.01 \mathrm{NS}\end{aligned}$ \\
\hline$R_{\mathrm{YL}, \mathrm{D}, \mathrm{HL}, \mathrm{HI}}^{2} \cdot \mathrm{BMS}=0.94$ & $\begin{array}{r}R^{2}{ }_{Y L D}, \mathrm{HI}, \mathrm{HI}^{2}=0.13 \\
\mathrm{SSE}_{\mathrm{YLD}}(\mathrm{BMS})=213,302.41 \\
\mathrm{SSE}_{\mathrm{YLD}}\left(\mathrm{HI}, \mathrm{HI}^{2}, \mathrm{BMS}\right) \\
12,053.80\end{array}$ \\
\hline
\end{tabular}

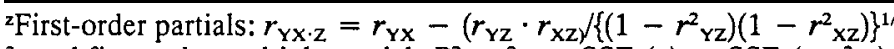
${ }^{2}$; and first-order multiple partial: $R_{y, x, x^{2} \cdot z}^{2}=\operatorname{SSE}_{y}(\mathrm{z})-\operatorname{SSE}_{\mathrm{y}}\left(\mathrm{x}, \mathrm{x}^{2}, \mathrm{z}\right) /$ $\operatorname{SSE}_{\mathrm{y}}(\mathrm{z})$.

y All $r^{2}$ values were significant at $P_{\alpha} \leq 0.05$, except $r_{\text {EGR,DTM }}^{2}$ had $P_{\alpha}$ $=0.1994$.

$\times$ BMS $=$ biomass; $\mathrm{BGR}=$ biomass growth rate; DTM $=$ days to maturity; DPF = days of pod fill; EGR = economic growth rate; $\mathrm{HI}$ $=$ harvest index; and $S G R=$ seed growth rate.

is a greater sink than source for assimilates, while biomass is the reverse-a greater source than sink. Seventeen accessions had a higher SGR than BGR. This finding suggested good translocation ability, strong sink strength, and/or that assimilates were remobilized during the generative phase. Additionally, these 17 accessions had harvest indices above the optimum of $57.2 \%$, but there was no consistent pattern for yield or biomass (see Table 4).

From these data, we propose a measure of relative sink strength (RSS) defined as:

$$
\mathrm{RSS}=\mathrm{SGR} \cdot \mathrm{BGR}^{-1}
$$

where: $\mathrm{SGR} / \mathrm{BGR}=\left(\right.$ seed yield $/ \mathrm{m}^{2}$ per DPF $) \cdot\left(\right.$ biomass $/ \mathrm{m}^{2}$

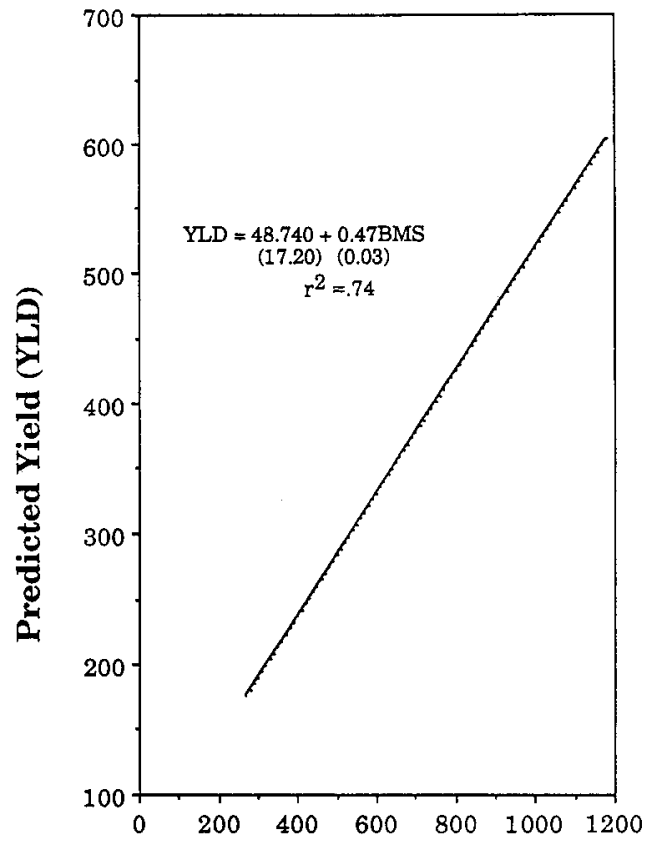

Biomass (BMS)

Fig. 4. Predicted yield $\left(\mathrm{g} \cdot \mathrm{m}^{-}{ }^{2}\right)$ of common beans as a function of plant biomass $\left(\mathrm{g} \cdot \mathrm{m}^{-2}\right)$, with SES of the regression coefficients shown parenthetically.

per DTM) $)^{-1}$ thus:

$$
\mathrm{RSS}=\mathrm{HI} \cdot\left(\mathrm{DTM} \cdot \mathrm{DPF}^{-1}\right) .
$$

Accessions with RSS values $\geq 1.0$ were judged useful for the improvement of yield in common beans. If the $\mathrm{HI}_{\max }, \mathrm{DTM}_{\max }$, and $\mathrm{DPF}_{\text {opt }}$ values developed earlier are substituted back into [Eq. 3], then: $\mathrm{RSS}=0.572 \cdot(112.2 / 63.7)=1.00$, and the theoretical ideotype would have a $\mathrm{SGR} \approx \mathrm{BGR}$. When these two traits are equated to their respective prediction equations, SGR and BGR are equal (intersect) $8.34 \mathrm{~g} \cdot \mathrm{m}^{-2} \cdot \mathrm{day}^{-1}$ (Fig. 5). The use of this ideotype in upstate New York would give seed and biomass yields of $\approx 530$ and $935 \mathrm{~g} \cdot \mathrm{m}^{-}{ }^{2}$, respectively.

The regressions of yield onto the growth rates (BGR, EGR, and SGR) were linear, positive, and highly correlated (Table 2, 


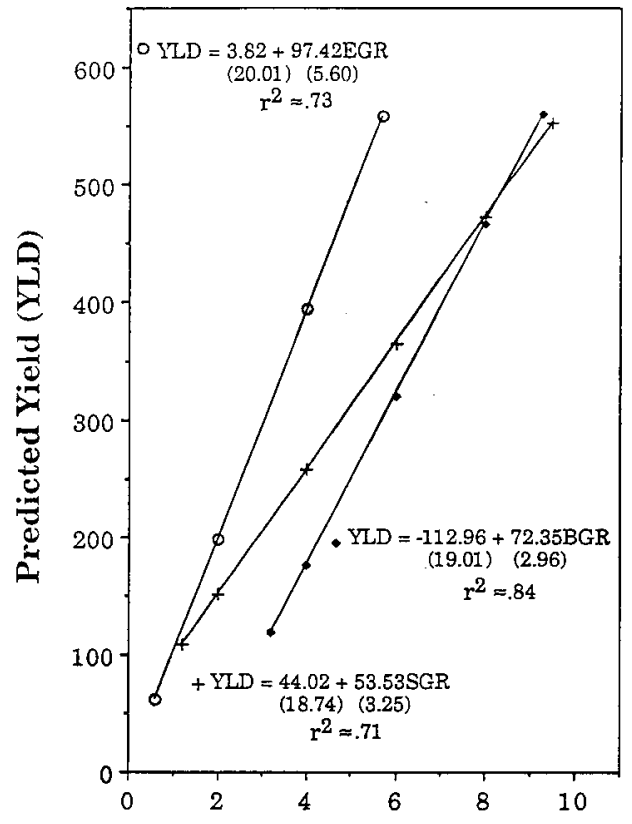

\section{Growth rates (BGR, EGR, and SGR)}

Fig. 5. Predicted yield $\left(\mathrm{g} \cdot \mathrm{m}^{-2}\right)$ of common beans as a function of the biomass growth rate (BGR), economic growth rate (EGR), and seed growth rate $(\mathrm{SGR})\left(\mathrm{g} \cdot \mathrm{m}^{-2} \cdot \mathrm{day}^{-1}\right)$, with SES of the regression coefficients shown parenthetically.

Fig. 5). These three correlations could have been influenced by DTM or DPF, which were used as denominators in the computation of the growth rates. Additionally, these diverse accessions completed their vegetative and generative phases at different times throughout the season, suggesting that slightly different environments influenced the expression of each trait (DTM and DPF). Partial correlation analysis was used to explore the possibility of spurious correlations (Table 5) (Draper and Smith, 1981). The first-order partials showed the limited influence of DTM or DPF, when compared to their respective simple correlations (Table 5).

The slopes of these regressions were as expected (Fig. 5). Since yield data were the same for each model, slopes were a function of the range of the predictor $r$. A shorter range resulted in a steeper slope. Economic growth rate had the shortest range $\left(5.1 \mathrm{~g} \cdot \mathrm{m}^{-2} \mathrm{day}^{-1}\right)$ and the steepest slope (97.42), while seed growth rate had the greatest range $\left(8.3 \mathrm{~g} \cdot \mathrm{m}^{-2} \cdot \mathrm{day}^{-1}\right)$ and the lowest slope (53.53). The biomass growth rate was intermediate (Fig. 5, Table 1). Clearly, seed growth rate showed greater variation upon which to practice selection, but increases in EGR inferred greater yield increases.

Within the context of Rasmussen's (1987) more broadly defined ideotype, variation existed for all the yield system traits evaluated in this study. Some of the traits were included in the bean ideotype previously defined by Adams (1982), although specific ranges were not identified. Optimum ranges for the New York environment were determined for $\mathrm{HI}$ (53.8\% to $60.6 \%$ ), DTM (107.8 to 116.6 days), and DTF (47.9 to 49.0 days). Growth rates, biomass, and days of pod fill were positive and linearly related to yield. Coefficients of determination were highest for the relationship between yield and biomass $\left(r^{2} \approx\right.$ $0.74)$, DTF $\left(R^{2} \approx .80\right)$, and the growth rates $\left(\mathrm{r}^{2} \approx 0.84,0.73\right.$, and 0.71 for BGR, EGR and SGR, respectively). Days to ma- turity $\left(R^{2} \approx 0.25\right)$, DPF $\left(r^{2} \approx 0.09\right)$, and $\mathrm{HI}\left(R^{2} \approx 0.13\right)$ were less useful for explaining yield. This ideotype, combined with a morphological ideotype, can help define a set of breeding objectives.

The multiple regression model (Table 3) was meant to define a unique combination of days to flower and pod fill that could maximize yield. This approach had a theoretical appeal, but could not be used because yield was linearly related to the pod fill duration. If a local maximum had existed within the biological range, our method could have defined the phonological ideotype. The indirect computation [Eq. 1] was used as a first approximation. We further proposed an equation called relative sink strength (RSS) [Eqs. 1 and 2], which specifically described Adams' (1982) "high rate of seed-filling" and "remobilization during. . seed filling". Accessions with RSS $\geq 1.0$ had seed growth rates greater than their biomass growth rates on a seasonal basis.

An ancillary benefit of this study was the identification of high-yielding exotic accessions. The top 5\% included accessions PI 310740, 'Emp-83', 'Turrialba-2', 'Suchitan' A-343, 'Peru34', 'Jamapa', and 'Linden', the only domestically developed cultivar (Table 4). In many crops, increases in yield have been related to changes in HI. In common beans, biomass, DTF and the SGR appear to be as important as HI. We speculate that breeders have selected two pathways for higher yield. Accessions such as 'Emp-83', 'Peru'34', and 'Linden' are long-cycle cultivars (DTM $\geq 120$ days) with high biomass growth rates and the larger biomass needed to carry greater yields (Table 4). Accessions such as A-343, 'V-7593', and 'Ms. Kelly' have higher harvest indices, SGR > BGR, shorter life cycles, and generally partition photosynthate more effectively. PI 310740 had the highest yield, growth rates, maintained a large biomass, and a high harvest index, which suggested that these pathways are not mutually exclusive, and could be combined for higher yield.

\section{Literature Cited}

Adams, M.W. 1982. Plant architecture and yield breeding. Iowa State J. Res. 56:225-254.

Apel, P. 1984. Photosynthesis and assimilate partitioning in relation to plant breeding, p. 163-185. In: P.B. Vose and S.G. Blixt (eds.). Crop breeding - a contemporary basis. Pergamon, New York.

Arya, J.C. and R.W. Lardner. 1979. Mathematics for the biological sciences. Prentice-Hall, Englewood Cliffs, N.J.

Austin, R. B., J. Bingham, R.D. BlackWell, L.T. Evans, M.A. Ford, C.L. Morgan, and M. Taylor. 1980. Genetic improvements in winter wheat yields since 1900 and associated physiological changes. J. Agr. Sci. Cambr. 94:675-689.

Beadle, C. L., S.P. Long, S.K. Imbamba, D.O. Hall, and R.J. Olembo. 1985. Photosynthesis in relation to plant production in terrestrial environments. Vol. 18. Natural resources and the environmental series. U.N. Environment Programme. Tycooly, Oxford, U.K.

Boerma, H.R. and D,A. Ashley. 1988. Canopy photosynthesis and seed fill duration in recently developed soybean cultivars and selected plant introductions. Crop Sci. 28:137-140.

Draper, N.R. and H. Smith. 1981. Applied regression analysis. Wiley, New York.

Duncan, W. G., D.E. McCloud, R.L. McGraw, and K.J. Boote. 1978. Physiological aspects of peanut yield improvement. Crop Sci. 18:10151020.

Evans, L.T. 1980. The natural history of crop yield. Amer. Sci. 68:388397.

Evans, L.T. 1983. Raising the yield potential: by selection or design, p. 371-389. In: T. Kosuge, C.P. Meredith and A. Hollaender (eds.). 
Genetic engineering of plants: an agricultural perspective. Basic life sciences. vol. 28. Plenum, New York.

Evans, L.T. 1984. Physiological aspects of varietal improvement, p. 121-146. In: J.P. Gustafson (cd.). Gene manipulation in plant improvement. 16th Stadler Genetics Symp. Plenum, New York.

Federer, W.T. 1955. Experimental design: theory and application. Oxford \& IBH, Bombay.

Gay, S., D.B. Egli, and D.A. Reicosky. 1980. Physiological aspects of yield improvement in soybeans. Agron. J. 72:387-391.

Gifford, R.M. and L.T. Evans. 1981. Photosynthesis, carbon partitioning and yield. Annu. Rev. Plant Physiol. 34:485-509.

Gifford, R. M., J.H. Thorne, W.D. Hitz, and R.T. Giaquinta. 1984. Crop productivity and photoassimilate partitioning. Science 225:801807.

Good, N.E. 1986. Confessions of a habitual skeptic. Annu. Rev. Plant Physiol. 37:1-22.

Good, N.E. and D.H. Bell. 1980. Photosynthesis, plant productivity and crop yield, p. 3-51. In: P.S. Carlson (cd.). The biology of crop productivity. Academic, New York.

Knott, D.R. and G. Gebeyehou. 1987. Relationships between the lengths of the vegetative and grain filling periods and agronomic characters in three durham wheat crosses. Crop Sci. 27:857-860.

Laing, D. R., Kretchmer, P. J., S. Zuluaga, and P.G. Jones. 1983. Physiological studies on yield and adaptation in Phaseolus vulgaris L., p. 227-247. In: S. Yashida (cd.). Potential productivity of field crops under different environments. Intl. Rice Res. Inst. Los Banes, Philippines.

Larsen, R.J. and M.L. Marx. 1985. An introduction to probability and its applications. Prentice-Hall, Englewood Cliffs, N.J.

Mood, A. M., F.A. Graybill, and D.C. Bees. 1974. Introduction to the theory of statistics. 3rd ed. McGraw-Hill, New York.

Myers, J.R. 1987. 38th annual report of the cooperative dry bean nurseries. Univ. of Idaho, Kimberly.

Neter, J., W. Wasserman, and M.H. Kutner. 1985. Applied linear regression models. 2nd ed. R.D. Irwin, Inc., Homewood, Ill.
Rasmussen, D.C. 1987. An evaluation of ideotype breeding. Crop Sci. 237:1140-1146.

SAS Institute, Inc. 1985. SAS user's guide: statistics, version 5.14 ed. SAS, Cary, N.C.

Searle, S.R. 1965. The value of indirect selection: I. Mass selection. Biometrics 21:682-707.

Sherrard, J. H., R.J. Lambert, M.J. Messmer, F.E. Below, and R.H. Hageman. 1984. Search for useful physiological and biochemical traits in maize, p. 51-66. In: P.B. Vose and S.G. Blixt (eds.). Crop breeding - a contemporary basis. Pergamon, New York.

Sinha, S.K. and M.S. Swaminathan. 1984. New parameters and selection criteria in plant breeding, p. 1-31. In: P.B. Vose and S.G. Blixt (eds.). Crop breeding - a contemporary basis. Pergamon, New York.

Turner, H.N. and S.S.Y. Young. 1969. Quantitative genetics in sheep breeding. Cornell Univ. Press, Ithaca, N.Y.

Wallace, D.H. 1980. The genetics of photosynthesis and crop productivity: with emphasis on beans, p. 306-317. In: M.E. Vartanian (cd.). Proc. 14th Intl. Congr. of Genet. vol. 1. book 2. MIR Publ., Moscow.

Wallace, D.H. 1985. Physiological genetics plant maturity, adaptation and yield. Plant Breeding Rev. 3:167-231.

Wallace D.H. and H.M. Munger. 1966. Studies of the physiological basis for yield differences: II. Variations in dry matter distribution among aerial organs for several dry bean varieties. Crop Sci. 6:503507.

Wallace, D. H., M.M. Peet, and J.L. Ozbun. 1975. Studies of $\mathrm{CO}_{2}$ metabolism in Phasolus vulgaris L. and applications in breeding, $\mathrm{p}$. 43-58. In: R.H. Burris and C.C. Black (eds.). $\mathrm{CO}_{2}$ metabolism and plant productivity. University Park Press, Baltimore.

Wallace, D.H. and P.N. Masaya. 1988. Using yield trial data to analyze the physiological genetics of yield accumulation and the genotype $\mathrm{x}$ environment interaction effects on yield. Annu. Rpt. Bean Improvement Coop. 30:vii-xxiv.

Zelitch, 1.1982. The close relationship between net photosynthesis and crop yield. Bioscience 32:796-802. 